\title{
POWER AND TACTICS IN BARGAINING
}

\author{
SAMUEL B. BACHARACH and EDWARD J. LAWLER*
}

This paper develops and tests an analytical tramework for analyzing the selection of tactics in bargaining. Using a variant of power-dependence theory, the authors propose that bargainers will use different dimensions of dependence, such as the availability of alternative outcomes Irom other sources and the value of the outcomes at stake, to select among different tac. tics. TC test this modcl, the authors conducted two simulation experiments that portrayed an employce-employer conflict over a pay raise, manipulating four dimensions of dependence: employec's outcome alternatives, employee's outcome value, employer's outcome alternatives, and employer's outcome value. Within this context, respondents estimated the likelihood of each actor (employec, enployer) adopting four tactics: self-enhancement, coalition, threat to leave, and conflict avoidance. The results of one experiment show that an actor's own dependence, rather than his opponent's dependence on him, is the primary basis for his evaluation and selection of tactics, and also that decisions regarding different tactics are determined by different dimen. sions of dependence. The results of the other experiment indicate that the opponent's initial tactic alfects the links between dimensions of dependence and an actor's tactics, and the dimensions of dependence affect the propensity toward "tactic matching."

B ARGaINING behavior is typically pre. ceded by an evaluation of the available tactics and of the power relationship between the bargainers. Indeed, it would be

\footnotetext{
"Samucl B. Bacharach is ith associalc projessor of in. dustrial and labor relations a the New York State School of Industrial and I aljor Relations at Cornell Universily and Edwartel J. Laswler is an associate professor ol sociology at The University of lowa. 'The order of authorship does not rellect a difference in contributions to this studly, which tuas truly been a joint enteavor. The autlors woukl like to thank Situart Freedman, L.niry liaffner, Stuars Stover and Paus Kline for assistance in the data collection or analysis, and Jae. On-Kim, Stepluen Michell, and especially Joseph Slsedd for lse]plul commenens.
}

Loolhardy to adopt a particular bargaining stance without a careful evaluation of the power and tactics available to oneself and to one's opponent. An analysis of this process, to have both theoretical and practical im. port, must therefore specify the dimensions of employee and employer power, classify the relevant tactics, and relate the power dimensions to the evaluation and selection of tactics. This research develops such an analytical framework and tests some major implications of the framework under highly controlled conditions.

The studies of Chamberlain and Kuhn, Stevens, and Walton and McKersie present 
theoretically illuminating and empirically insightful analyses of bargaining tactics. ${ }^{1}$ These authors fail to relate the tactical aspects of bargaining, however, to an explicit theory of bargaining power. The link between bargaining power and bargaining tactics is simply assumed and left undeve]. oped on a theoretical and empirical level. The failure to articulate the commection between power and actics is partly due to the fact that students of collective bargaining adopt a nonanalytic approach to power. $\Lambda$ s noted by many writers, power has remained a blurred analytic construct in the collective bargajuing literature. ${ }^{2}$

We have argued that a theory of bargaining lactics must be based on an explicit, multidimensional conceptualization of powet and that the parties' selection of tactics is ultimately based on their evaluation of the dimensions of power. ${ }^{3}$ The evaluative process that underlies tactical action in bargaining ran be divided into three steps. First, bargainers evaluate their own power capability and that of their opponents. Second, given these perceptions of power, bargainers consider the likelihood that the power capalility will actually be used. Third, in the context of their power situation, bargainers evaluate their own tactical options and attemyt to anticipate their

\footnotetext{
'Neil W. Chamberlain and James W. Kutun, Collective Aargaining (New York: McCiraw.Hill, 1960), Cow] M. Sievens, Stratesy and Collective Bargaining Nego. tintion (Now Yo1*: McCiraw-Hill, 1963), and Richarel E. Waltom and Rolser B. Mekersie, A Behaxional Theory of Labor Negotiations (Now York: MrGinw. Hill, 1965).

'Sec, for example, Charles E. L, indblon, "'Bargain. ing Power" in Price and Wage Determination," The Quarterly Joumal of Economics, Vol. 62 (May 1948 ), pp. $896-117$; Bobert Dubin. "Power and (1nion. Mabagemeol Relutions," Administrative Science Qunrierly, Vol. 2, No. 1 (June |057), pp). 60-Bl; and Gerald C. Somers, "Bargaining Power and Industrial Relations Tlueory," in Gerald G. Somsers, ed., Fissays in Industrial Relations Theory (Ames, lowa: Jowa Statc University Ptess, 1969), pp. 39- 53.

Samuel B. Hacharach and tidwatrd J. L atwler, Power and Politics in Organizations: The Social Psychology of Conflict, Contitions, and Bargaining (San Frant. cisco: Josscy-13ass Publishers, 1980), and Edward J. Lawler and Samuel B. Bacharach. "P'ower Dependence in Individual Bargaining: The Expected Utility of Inlluence," Indusirial and Iabor Relotions Revieu, Vol. 92 . No. 2 (Janutiry 1975). pp. 196-204.
}

opponent's tactics. The first two issues were examined in prior research by the authors; the third step is the key tactical dilemma confronting bargainers and the prime concern of this paper.

\section{Power as Dependence}

We have argued that the notion of power embedled in power-dependence theory provides a flexible and insightful backdrop for both researchers and practitioners to deal with the power and tactical aspects of bargaining. ${ }^{5}$ First of all, the theory offers a multidimensional conceptualization of power that identifies and differentiates the specific bases of employee-employer power; second, the theory provicles a foundation for identilying broad tactical options and for positing empirical links between bases of power and the tactics an actor may select in a bargaining situation. Each of these advantages is developed in the following pages.

Power-dependence theory stipulates that one party's power is a function of the other's dependence, which varies direcly with the value the second party attributes to the out. comes at slake (outcome value) and inversely with the availability of the same or bettet outcomes from alternative sources (outcome alternatives). ${ }^{\circ}$ Outcome value is viewerl as the "importance of" or "need for" the outcomes in question, rather than outcome magnitude.? Take an employee-

\footnotetext{
'Samued B. Bachaurich and Ldward J, Lanwler, "The Perecetion of Power." Social forces, Vol. 55, No. I (S|celeruber 1976), pp. |23-94, and l awler and Barha. ratch, "Power Dependence in Individual bargaining."

'llacharach atnd Latwler, Power and Politics in Organizations.

GRiclaril M. Fonerson, "l'ower-Dependence Relations," American Sociological Revicw, Vol. 27, No, 1 (February 1962), Dp. 3I-40; Richard M. Emerson, "Exclange Theory Part I: A Psychological Basis for Social Cilantge," in Joseph Berger, Morris Zelditch, Jr. and Bo Amkerson, eds., Sociological Theories in Prog. ress, Vol. 2 (Boston: Houghıon Mil(lit, 1972); and 11. Andrew Michener and Robert WW. Suchener, "The 'Iaclical Use of Social Power," in Janes T. Tedesclit. ed., Social mofuence Processes (Chicago: Aldine. Atherton, 1972), pp. 239-80.

'Bacharach and Lawler, Power and Politics in Or. ganizations; Peter M. Blau, Exchange and Power in Social Life (New York: Jolu Wiley and Sons, 1961): E.merson, "Power-1)ependence Relations"; Ketneth
} 
employer conflict as an example. Powerdependence theory suggests that the $\mathrm{cm}$ ployee is dependent on the employer to the extent that the employee has poor alternatives and values the outcomes at issuc highly while the employer is dependent on the employec to the extent that the employer has poor alternatives and values the outcomes highly. Overall, the employees' dependence on employers is determined by their own situation (the employee's own alternatives and outcome value), and the employers' dependence is determined by their own situation (the employer's own alternatives and outcome value).

The power-dependence perspective implies a variable sum approach to power, in contrast to the conventional zero-sum approaches that prevail in the bargaining field. A zero-sum approach stipulates that an increase in one party's power, by definition, implies a decrease in the other's power; this assumes that there is a finite, unchanging level of "total" power in the relationship. Zcro-sum conceptualizations focus on relatize power and assume constant tolal power. 'This is an important distinction, because if we apply the zero-sum as. sumption to the dependence relationship of parties, it leads us to conclude that any change in one party's dependence will have an equal and opposite effect on the other's dependence. On the oller hand, a variable sum approach recognizes that total as well as relative power may vary and treats the relationship between the Iwo parties' power (dependence) as an empirical question.

Total power refers to the sum total of dependence in the relationship: the dependence of $A$ on $B$ plus the dependence of $B$ on $A$. Relative power is the ratio of one party's

J. Gergen, The Psychology of Behavior Exchange (Menlo Park, Cal.: Aldjsou-Wesley, 1969); Jolun W. lhibaut and Iarokl H. Kelley, The Social Psychology of Groups (New York: John Wiley \& Soms, 1959). Oulcome alternatives represent a notion that is virtually itcutical to 'Tlubaut and Kelley's "Comparison Level for Alternatives." It is the level or quality of aluernatives that is important, not the nunlyer. It takes only one good alternitive to emhance the power of a party; the tuunler of aliemalives is only important insofar as it enhances the probibility of getting better outcomes elsewhere. dependence to the olher's dependence: $\Lambda$ 's relative power refers to the ratio of B's dependence on A to A's dependence on B, while B's relative power is the ratio of $A$ 's dependence on B to B's dependence on A. These ratios are the reciprocal of one another and, therefore, relative power is inherently zero-sum. However, the fact that total power is analytically distinct from relative power means that there is no a priori connection or relationship between relative and total power. Total power can change with or withoul a clange in relative power and vice versa.

To exemplify the relationship between total and relative power, consider a situa. tion in which the ratio of $A$ 's power to $B$ 's power is 2 to 1 . Assume the "resources" that constitute power in the context can vary from 0 to 20 on some hypothetical continuum and that the maximum total power in the relationship is 20 . Given this tolat power, the same relative power (2 101 ratio in favor of $A$ ) could occur under different levels of total power: $\Lambda=4 \mathrm{vs}, B=2$ or $A=10$ vs. $B=5$, for example. Thus, the total power can change while the relative power remains the same. Next, let us see how changes in relative power can affect totil power. Take the situation in which $A$ controls 4 units of some power resource while $B$ controls 2 units. If $A$ increases his resources from 4 to 6 by developing access to more of the total power theoretically available in the rela(ionship, then there would be a slight increase in total power (Irom 6 to 8 ) and a shift in the relative power to a ratio of $3: 1$. However, a simultaneous or sequential accumulation of resources by $\mathbf{B}$ could maintain the original 2 to 1 ratio and produce an even larger increase in total power, Finally, rclaive power can also shift while maintaining the same level of total power, as it would if $A$ moves 105 and $B$ to 1 . Overall, this conceptualization leads to the conclusion that the two parties can simultaneously incrense in power just as they cam simulianeonsly experience a reduction in power. $A \mathrm{n}$ increase in one party's power does not necessarily (and certainly not by definition) lead to are. duction in the other's power.

Applied to power-dependence theory, a variable sum approach suggests that the 
interrelationships among the four dimensions of dependence-cmployee's outcome alternatives, employee's outcome value, employer's outcome altermatives, employer's outcome value-are important tactical questions confronted by actors in a bargain. ing situation. On an "objective" level, there may bea zero-sun relationship among some aspects of the dimensions. For example, an increase in the wage tate may affect the em. ployee's and employer's outcome value in an cqual but opposite way; or a slack labor market may mean few alternatives for the employec and many for the employer. How. cver, the relationships among these dimensions of dependence are not necessarily that simple. While an increase in the wage rate may be highly important to the conployee, it may lse irrelevant to an employer who can easily pass on the cost of the wage increase to customers; similarly, a tight labor market for the employer might make altemative jobs available to the employee while atlvances in technology might minimize the amployer's need for the employees; or a slack laljor market for the employer could de. crease the employec's altermatives while bigh training costs could counterbalance the effects of the slack labor market on the employer's alternatives. The point is that the "objective" relationships among these dimensions of dependence are very complex and that point, combined with the fact that parties typically have only imperfect information on the pertinent social, economic, or political conditions, make the "subjective" or perceptual aspects of these relationslips of prime concern to an analysis of tactics.

Overall, the dimensions of dependence provide actors a shorthand way to summarize and synthesize the power implicalions of the social, economic, and political conditions. In this sense, the dimensions of dependence are as much a perceptual phenomenon as they are "objective" teatures of the bargaining context. The interrelationship of the dimensions of dependence is primarily a matter of perception, especially is they relate to the tactical decisions in largaining. It would not be appropriate to assume that parties will treat the dimensions in a zero-sum manner even il that were the nature of the relationship on an "oljece. tive" level. It is just as reasonable, given our distinction between total and relative power, to assume that actors will treat the dimensions of their own dependence and of their opponents' dependence in a distinct and independent manner. We make neither assumption and suggest that this is an open question.

\section{Power and Tactical Action}

The tactical implications of the power. dependence theory vary somewhat with how one interprets the connection between dependence and power. The foregoing discussion represents a strict interpretation of the theory. It indicates that the power of a party is determined, not by the party's own dependence, but by his opponent's dependence. Consistent with the variable sum elements of the theory, encli party's power is independently determined by the other's dependence on him, and a decrease in one party's dependence does not automatically increase the other's dependence. Our interpretation suggests a further distinctionbetween tactics that deal with one's own dependence and tactics that deal with the opponent's dependence, in other words, between the opponent's power over oneself and onc's own power over the opponent. This distinction may be especially importane in the evaluation of tactics, and we will return to it later.

'This researct: will examine specifically the impact of the four dimensions of de. pendence on parties' evaluation and prediction of lactics. Two experiments are presented. 'The first experiment is concened with three interrelated issues: (1) whether parties (employees and employers) use dimensions of their own or the other's dependence to evaluate their own tactical options, (2) whether parties usc these same dimensions of dependence to predict the other's tactics, and (3) whether the role (cmployec, employer, or observer) of the parties alters their use of the dimensions of dependence to evaluate and predica the tactics of the employee and employer.

$A$ second experiment in this paper carries the analysis of tactics one step lurther. The first experiment deals only with the 
initial or first tactic. The second deals with the question of how dependence affects the prediction of tactics at the next stage in the conflict, after one of the parties has adopied a given tactic. Specifically, experimenı 2 is concerned with: (1) what dimensions of dependence will parties use to predict the other's countertactical response and (2) will the dimensions of dependence affect the extent to which employees and employers anticipate tactic reciprocation, that is, apply a "lactic matching" principle.

In an earlice study, we attempted to deal with the first issue specilied above-whether parties use dimensions of their own or the other's dependence to evaluate their own tactical options. ${ }^{8}$ The primary import of that study was that it established the empirical relevance of the tactics incorporated in the present researcl. As in that study, this research is concerned with an employceemployer situation in which the conflict is over a specilic temporally bound issue (a pay raise). Within this context, the $\mathrm{cm}$. ployee and employer have at least four op(ions: (1) coalition (joint action with others in similar positions); (2) threat to leave the relationslip (for employee, a threat to quit; for employer, a threat to replace the $\mathrm{cm}$ ployec); (3) self-enhancement (persuading the other than one's inputs to the relationship warrant the outcomes at stake); and ( 1 ) conflict avoidance (resigning oneself to do without the outcomes at stake). ${ }^{9}$

In line with our approach to power-dependence theory (discussed alove), we will distinguish between those tactics that are based on a party's own dependence on the opponent (that relate to the other's power); and those tactics that are based on the opponent's dependence on self (that relate to one's own power). We will refer to the first set as "direct" tactics and the second set as "indirect" tactics. "Direct" tactics are

st atwler and Bachanacl,, "Outcome Alternatives and Value as Criteria for Multitactic Evaluatlions."

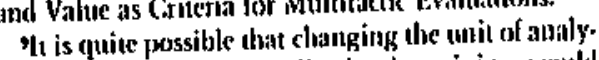
is from intividetal to collective bargaining would alter the littks be(ween dependence and tactical toptions aller the hiths the restarch. While we are convinced that the same framework applies to both individual abul collective bargainiang, we tesene for the future the question of how the two might ice cualitatively differcint. grounded in a party's own dependence on the other. These tactics include a threat to leave the relationship and conflict avoidance, $A$ threat to leave uses the party's own alternatives and conflict avoidance uses the party's own outcome value. In contrast, "indirect" tactics manipulate the opponent's ability to use direct tactics by altering the opponent's dependence (hence, the label, "indirect"). A coalition can reduce or blunt the alternatives available to the ofpponent and thereby alter the opponent's ability to use a threat-to-leave tactic. Self-enhancement, if successlul, alters the value the other attributes to the outcomes at stake by em. plasizing that one's own inputs to the relationship compensate for the ollier's loss of the outcomesal stake. In sum, two tactics use a party's own situation (threat to leave and conflict avoidance) and two tactics are directed at the opponent's situation (coalition and self-enhancement).

\section{Hypoticeses}

We expect different dimensions of dependence to affect different tactics. This expectation is based on two assumptions. liirst, persons will use the level of alternatives and the value of the outcomes at stake to identify points of strenglh or weakness in each other's situations. Second, different tactics can deal with different sources of strength or weakness. An actor with good alternatives, for example, should perceive a threat to leave as a more viable strategy, and lower levels of outcome value should make conflict avoidance more palatable. The basic implication of the forcgoing assumptions is that different tactics deal with different dimensions of dependence and, therelore, persons will use different dimensions of dependence to evaluate different tactics.

Our expectation can thus be defined in lour basic hypolleses. (In each one, the dependent variable is a tactic available to an "actor," as distinguished from an "opponent"; the "actor" can refer to either the employee or employer.) (1) The better an actor's perceived altermatives, the greater the likelihood of a threat to leave by the actor; (2) The lower the value an actor ascribes to the outcomes at issue, the greater the likelihood of conflict avoidance by the actor; (3) 
The better the opponent's perceived alterna. tives, the gieater the likelihood of a coalition lactic by the actor-since a coalition can reduce the opponent's ability to use his alternatives; and (4) The lower the oppo. nent's outcome value, the greater the likeli. lood of self-enhancement by the actorsince a relatively soft strategy, such as selfenhancement, becomes more effective if the other attaches low value to the outcomes. Each liypothesis indicates that one tactic should be especially sensitive to variation in one of the dependence dimensions. The hypollieses suggest where we should find the strongest links between the dimensions of dependence and the tactics, but they do not preclude the possibility of other unpredicted effects.

\section{Expcriment One}

\section{Methoul}

Subjects and procedures. The data for this study were collected along with the data for an earlier paper. ${ }^{10} \mathrm{~A}$ rolc-playing simu. lation manipulated the four dimensions of dependence in a $2 \times 2 \times 2 \times 2$ factorial design. A total of 528 undergraduaties from two Northeastern universities were randomly assigned in equal numbers to one of the sixteen experimental treatments. The role (employec, employer, observer) adopted by the subject was counterbalanced within each experimental condition to assure that the effects of depentence could not be attributed to the particular standpoint (role) of the subject and to permit an analysis by role.

Before responding to a questionnaire, subjects read a description of a situation in which the employer (mamager-owner of a clothing store) was in the process of deciding whether to increase the pay of some or all salespersons." 'Ihe employer had told the

10See Latwler and Bachatrach, "Outcome Alternatives and Value as Criseria for Multiaclic Evaluations," for at more complete description of the urethodolosgy and a discussion of the advantages and disadyantages of our role-playius method.

"We dil not specify how much of a pay increase the enployec was asking Ior in the study. While this is not a trivial issue, we felt that it was better to leate this ambignous. 'l'te reason is that our outcome value manipulation deals with the importance of lie oul. employee that he is currently against giving pay raises but will make the final decision in about two weeks. In this context, the "description of the situation" stated:

[The employee] is [aced with deciding whether to toy to influence [the employer] before he makes the final decision. ['The employee] has the following options: ]) as an individual, [ the employce] could threaten to find anoulier job; 2) . . .try to persuate [the employer] . . . by pointing to his good sales perlotmance; 3) . . . join with other sales personnel and, as a group, attempt to pressure [ the employer] into giving pay raises; or 4). . . accept present pay and not try to influence [the employer]. Your task is to predict what options [the employed will select.

The description then indicated that the employer could respond to the action of the employec in a number of ways and listed the same set of oplions, adjusted, of course, for the employer role.

The description also contained information that manipulated the dimensions of dependence. 'The availability of alternative jols for the employee and altermative sales workers for the employer manipulated the two outcome-alternative variables. Spe. cifically, the manipulation of the employ. ce's alternatives indicated that there was a 10 percent or a 90 percent clance that [the employee] could find a better job, while the manipulation of the employer's alternatives indicated that there was a 10 percent or a 90 percent chance that the employer could hire another person with the employee's qualifi. cations. Outcome value was manipulated by varying the importance of getting a pay raise (for the employee) or avoiding a pay raise (for the employer). In brief, the manij)ulations stated the employee considered a pay raise as very important or not at all important (employee outcome value), and the employer considered it very important or not at all important to avoid pay raises (employer outcome value)..$^{12}$ Subjects were informed that both the employee and em. ployer had this information on each

comes at stake. If we hatd includerd some specific anount of pay, this could have weakened the oucome value manipulation and undemined our ability to test the effects of othcome valuc.

12|'or the exact wording of lie manipulations, see Lawler and Bacharich, "Power Dependence in Individual Bargaining." 
other's outcome alternatives and value, that is, both parties had information on all four dimensions of dejendence. ${ }^{13}$

Dependent variables. Separate questionnaire items for eacl of the four tactics asked subjects to (a) estimate how likely the employee would be to adopt the tactic, and (b) estimate how likely the employer would be to use each tactic in response to an influence attempt by the employee. Subjects responded on nine-point scales, labeled "not at al! likely" at the low end and "highly likely" at the high ent.

The four questionnaire items, measuring sulbjects' evaluation of the employee tactics, took the following form. "How likely is it that the employee would (a) "threaten to leave the store and find another job?" (threat to quil); (b) "try to persuade the employer... by pointing to his good sales performance?" (self-enhancement); (c) "organize with other sales personnel and, as a group, pressure the employer to give pay raises?" (coalition); (d) "decide to accept his current pay and not tiy to influence the employer?" (conflict avoidance). Items on the tactical response of the employerisked subjects to estimate the employer's response to an influence attempt, in general, without specitying the specific type of employec action (tactic) laken: "If the employee tries to influence the employer, how likely is it that the employer will . . ." The same items were included, with appropriate adjustunents for the employer position, ${ }^{14}$

\footnotetext{
131 should lec woted that we arte not atssuming that lourgaincers in real wotkl setuings bive complete intemtitation but that sudt jersoms will make subjer.

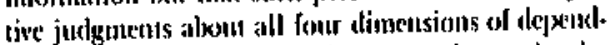
corce even in the fasce of inaderptate and very sketehy inlormation. To sumularize, we believe that the illformanion provided in the description is comparable to the overall subjective estimates that people might nake in real setings and dial if we ded mot provide information on all four climetisions, it wonld actually le more unerealistic because parties do make these kinds of judgments.

"Adelitional iems asked them how comlident they were in their estimates and how easy (or difficuld) it was to understand the description of the situation. Subjects responded ors nine-poitst scales, with bigher numbers indicating grester confidence or understanditug. On a nine poime scale, the mean confidence was 6.I and due mean level of unterstanding was 7.0 , suggesting considerable confidence and tuncler standing.
}

\section{Results}

There were two steps to the analysis. First, a multivariate analysis of variance (ANO. VA) was used to determine whether dimensions of dependence signilicantly affect multitactic predictions. Second, multiple regression was used to test the hypothesized eflects of outcome alternatives and value on particular tactics.

Multivariate ANOVA. Consider the mul(ivariate ANOVA for the employee's tactics (Table I) first. The multivariate analysis of variance revealed significant main effects for employee's altenatives $(\mathrm{F}=56.67, \mathrm{p}<$ .001 , canonical $\mathrm{R}=.55$ ) and employee's value $(\mathrm{F}=18.92, \mathrm{p}<.001$, canonical $\mathrm{R}=.36)$. There was no main effect for employer's value $(\mathrm{F}<\mathrm{l})$ or employer's alternatives ( $F=3.17$, $p<.01$, canonical $R=, 16$ ). None of the interaction effects between the dimensions of dependence were statistically significant; and a $2 \times 2 \times 2 \times 2 \times 3$ multivariate ANOVA wilh the subject-role (employee, employer, observer) as a factor revealed that the role occtupied by the perceiver did not interact with or specily the dependence effects. In sum, the mulitivariate ANOVA for the employee's tactics shows that individuals (regardless of role) use the employce's own dependence (employee's altematives and value), and not the other's (employer's) de. pendence, to predict the multitactic inclinations of the employee.

Next, consider the multivariate $A$ NOVA for the employer's response to the employce (Table 2). This analysis showed a main effect for employer's alternatives $(F=12.93$, $\mathrm{p}<.00 \mathrm{l}$, canonical $\mathrm{R}=.30$ ) and employer's value $(\mathrm{F}=8.78, \mathrm{p}<.001$, canonical $\mathrm{R}=.25)$, but no effects for the employec's alternatives ( $\mathrm{F}<1$ ) or employee's value $(\mathrm{F}=2.21, n s)$. None of the interactions were significant, and an analysis with role as a factor showed no inieractions by role. These results are consistent with the findings for the employee's tactics. Just as persons use the employee's dependence to predict the employee's multitactic tendencies, they use the employer's dependence siluation to predict the employer's response. ${ }^{15}$

\footnotetext{
13 It should be noted that he overall hactic rankings are consisicent with an carlier study (Lawler and Bacla. rach, "Outcome Altermitives and Value as Criteria
} 
Table 1. Main Effects of Dependence Dimensions on the Suljjective Likelihood of the Employee Adopting Each of the Four Tactics.

\begin{tabular}{|c|c|c|c|c|c|c|c|c|}
\hline \multirow{2}{*}{$\begin{array}{l}\text { Dimensions } \\
\text { Dependenc } \\
\text { Bmployee } \\
\text { Tactic }\end{array}$} & \multicolumn{2}{|c|}{$\begin{array}{l}\text { Bimployer's } \\
\text { Altematices }\end{array}$} & \multicolumn{2}{|c|}{$\begin{array}{c}\text { Enployer's } \\
\text { Valuor }\end{array}$} & \multicolumn{2}{|c|}{$\begin{array}{l}\text { Employee's } \\
\text { Aliematioes }\end{array}$} & \multicolumn{2}{|c|}{$\begin{array}{c}\text { Employes's } \\
\text { 'alite' }\end{array}$} \\
\hline & Low & Jigh & low & Ihigh & Low & High & Low & $\mathrm{Iigh}$ \\
\hline $\begin{array}{l}\text { Ihurest to } \\
\text { guil }\end{array}$ & 3.98 & 3.61 & 3.8 .3 & 3.77 & 2.66 & 4.91 & 3.18 & 4.11 \\
\hline $\begin{array}{l}\text { Condlict } \\
\text { aventelutuce }\end{array}$ & 3.17 & 9.86 & $9.5 \%$ & 3.81 & 3.94 & 3.36 & 4.24 & 3.05 \\
\hline $\begin{array}{l}\text { Sell } \\
\text { cultitucement }\end{array}$ & 6.56 & (6.)II & 6. 11 & 6,21 & (j.3.3.3 & fi... & 5.89 & i. 77 \\
\hline Costlitim & 4.83 & 1.79 & 1.83 & 4.72 & $4,6 \%$ & 1.92 & $4.3 k$ & $\{.19\}$ \\
\hline $\begin{array}{l}\text { Multivariale } \\
\text { ANOVA }\end{array}$ & \multicolumn{2}{|c|}{ ns } & \multicolumn{2}{|c|}{ its } & \multicolumn{2}{|c|}{$p<. \mid 01$} & \multicolumn{2}{|c|}{$p<.001$} \\
\hline
\end{tabular}

Table 2. Main Effects of Dependence Dimensions on the Subjective Likelihood of the limployer Responding with bach of the Four lactics.

\begin{tabular}{|c|c|c|c|c|c|c|c|c|}
\hline \multirow{2}{*}{$\begin{array}{l}\text { Eimployer } \\
\text { Tentic }\end{array}$} & \multicolumn{2}{|c|}{$\begin{array}{l}\text { Bimployer's } \\
\text { Alternatives }\end{array}$} & \multicolumn{2}{|c|}{$\begin{array}{l}\text { Employer's } \\
\text { Value }\end{array}$} & \multicolumn{2}{|c|}{$\begin{array}{l}\text { Limployee's } \\
\text { sitematives }\end{array}$} & \multicolumn{2}{|c|}{$\begin{array}{l}\text { Bmployee's } \\
\text { Valuer }\end{array}$} \\
\hline & Ions & High & tott & lligh & Low & lligh & Low & High \\
\hline $\begin{array}{l}\text { 'llurest to } \\
\text { rephace' }\end{array}$ & 3.60 & titio & 4.13 & 1.19 & 1.08 & 1.21 & 1.06 & 1,26 \\
\hline $\begin{array}{l}\text { Cinnflict } \\
\text { inveridlanece }\end{array}$ & 1.02 & 3,63 & 4,22 & 3.42 & 8.73 & $\$, 91$ & .3 .16 .5 & 159 \\
\hline $\begin{array}{l}\text { Self } \\
\text { enhlancentente }\end{array}$ & 6.13 & 5,42 & 5.45 & 6,07 & 5.81 & 5.74 & 5.67 & 5.88 \\
\hline Caxalition & 3.39 & 3.28 & 3.25 & 3.42 & $\$ 299$ & 3.37 & 3.23 & 3.14 \\
\hline $\begin{array}{l}\text { Mullivarjate } \\
\text { ANOWA }\end{array}$ & \multicolumn{2}{|c|}{$p<.01$} & \multicolumn{2}{|c|}{$p<,[(y)]$} & \multicolumn{2}{|c|}{ IIs } & \multicolumn{2}{|c|}{135} \\
\hline
\end{tabular}

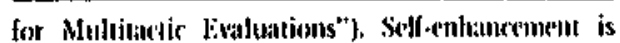
perceived as the most preferted tactic actoss experi. mental comditions, followed by coalition, threat oo leave, and contlict ansoidance. The onerall yankings are of minimal inportance, bowever, becusese diey are
Jikety to be a lunction of such consinut aspects of the social situation as the enuployerectuyloyen relationship athl conflict of interest. Moreover, the bypotloeses predia changes in actic predictions, not in the ranking of lactics. 
Table 3. Regression of Dimensions of Dependence on Subjective Likelihood of Employec and Employer Tactics (Separate Equations for Each Tactic).

(Unstandardized coefficients are in parentheses)

\begin{tabular}{|c|c|c|c|c|c|c|c|c|c|}
\hline $\begin{array}{l}\text { Pimensions of } \\
\text { Dependence } \\
\text { Predicted } \\
\text { J'ariables } \\
\text { (Thetics) } \\
\text { Employe Taclirs }\end{array}$ & \multicolumn{2}{|c|}{$\begin{array}{l}\text { Binployey's } \\
\text { Allersatiues }\end{array}$} & \multicolumn{2}{|c|}{$\begin{array}{l}\text { Eimployer's } \\
\text { V'alue }\end{array}$} & \multicolumn{2}{|c|}{$\begin{array}{l}\text { Employee's } \\
\text { Altermatives }\end{array}$} & \multicolumn{2}{|c|}{$\begin{array}{l}\text { Employer's } \\
\text { J'altur }\end{array}$} & $\begin{array}{c}\text { Equation } \\
\text { No. }\end{array}$ \\
\hline $\begin{array}{l}\text { Tlireat to } \\
\text { leave }\end{array}$ & -.08 & $(-. .87)$ & -.01 & $(.06)$ & $.52^{*}$ & $(2,29)$ & $.11^{*}$ & (.69) & 1 \\
\hline $\begin{array}{l}\text { Conflist } \\
\text { invoidtance }\end{array}$ & .09 & $(39)$ & .07 & (.28) & $-.15^{*}$ & $(-.62)$ &.$- .30^{*}$ & $(-1,23)$ & 2 \\
\hline $\begin{array}{l}\text { Sell- } \\
\text { enthancenent }\end{array}$ & -.10 & $(-., 1)$ & $-\underline{.03}$ & $(-.16)$ & .00 & $(.02)$ & $.21^{*}$ & $(.88)$ & 3 \\
\hline Coalition &.- .02 & $(-.10)$ & -.02 & $(-.11)$ & .06 & (.29) & $.17^{*}$ & $(.80)$ & 4 \\
\hline \multicolumn{10}{|l|}{ Eimployer T'actics } \\
\hline $\begin{array}{l}\text { Threal to } \\
\text { leave }\end{array}$ & $.25^{*}$ & $(.99)$ & .02 & $(, 07)$ & .04 & (.15) & $.0 \%$ & $(.20)$ & 5 \\
\hline $\begin{array}{l}\text { Conflica } \\
\text { aroidinoce }\end{array}$ & -.10 & $(-.39)$ & $-\underline{, 21}^{*}$ & $(-.79)$ & .05 & $(.18)$ & .09 & (.3.1) & 6 \\
\hline $\begin{array}{l}\text { Self- } \\
\text { enltanceuncul }\end{array}$ & $-.10^{*}$ & $(-.71)$ & $.11^{*}$ & (.59) & -.02 & $\{-.07\}$ & .05 & $(.21)$ & 7 \\
\hline Coslitions & -.03 & $(-.11)$ & . & $(.17)$ & .02 & $(.09)$ & .06 & (.21) & B \\
\hline
\end{tabular}

atypothesized relations are underlined.

$H p<.001$.

Table 3 contains the standardized (and unstandardized) regression coefficients from separate equations for each tactic. Comparing coefficients for each tactic sepa. rately (across each row of the table), we find that all hypotheses regarding power de. pendence effects on direct tactics (threat to leave and conflicl avoidance) were supported. As hypothesized, employec's alternatives had the largest effect (compared to the other independent varialles) on an employee threat to leave (Equation 1); and employer's altematives had ilie largest effect on the threat to leave response by the $\mathrm{cm}$. ployer (Equation 5). Employee's value had the largest effect on conflict avoidance by the employee (Equation 2); and employer's value had the largest effect on the perceived likelihood that the employer would respond with conflict avoidlance (Equation 6).

The importance of these results is further documented by comparing the effects of cach independent variable down the columns of the table. Across the various equations (down eacl column), the employee's alternatives affected the employee's threatto-leave tactic more than any other tactic, and the employer's alternatives alfected the employec's ihreat-10-Jeave tactic more than any other tactic. The same patterns exist tor the links between each party's outcome value and conflict avoidance. Furthermore, the direction of all these effects (lower value, greater likelihood of conflict avoidance; higher alternatives, greater threat-10-leave likelihood) is in accord with the Jyypollieses. In sum, data on direct tactics consistently provide support for the hypotheses.

In contrast, the data on indirect lactics (self-enhancement and coalitions) do not support the hypotheses (see Equations 3, 4, 7 , and 8). The opponent's (employer or employec) alternatives were not used to predict an actor's inclination toward coalitions, and 
the opponent's value was not used to make sell-enhancement predictions. In fact, the opponent's dejendence does not affect decisions regarding any of the specific tactics. All significant effects on specific strategies (sec upper right quadsant and lower left quadrant of Table 3) involve the acior's (whether employee or employer) own dependence situation.

\section{Discussion}

The findings can be understood in the context of our interpretation of powerdependence theory presented in the introduction. Recall that the dependence of the employee on the employer (in other worts. the employer's power) is determined by the employee's own alternatives and outcome value; whereas, the dependence of the $\mathrm{em}$ ployer on the employee (or the employee's power) is determined by the employer's own aliematives and outcome value. The most general implication of the first experiment is that individuals will use the employ. ec's own dependence (or employer's power) situation to evaluate and predict the $\mathrm{em}$ ployee's multitactic decisions, and the enployer's own dependence situation (or cmployee's power) to evaluate and preclict the employer's multitactic decisions. Given that the power is based on the other's dependence, this means that individuals perceive an actor's tactics (whether the employee or the employer) to loe based primar. ily on the ofpponent's power.

Within the foregoing constraint posed by the dependence structure (and reflected in the multivariate $A N O V / \mathrm{s}$ ), the resul(s al. firm the notion that different dimensions of dependence affect different tactics. A threat to leave is perceived as more likely when the actor (whether employee or employer) has high rather than low alternatives, and conflicl avoidance is perceived as more likely when the actor attaches low rather than high value to the outcomes at issue. Tanctics that are bised on the actor's own dependence situation (direct lactics) are evaluated and predicted from different aspects of the aceor's dependence (alıenratives vs, value). In contrast, tactics that attack the opponent's dependence situation (indirect tactics) are not consistently predicied from any of the dimensions of dependence. The data reveal a few other relationships as well, but these are minor. It is noteworthy that the rolc standpoint (employee, employer, observer) does not qualify the results for dependence. It appear's that inclividuals use the same criteria to predict olhers' lactics (whether from an opponent or observer standpoin!) as they do todevelop their own action plansi, to predict their ows behavior.

This first experiment examined how individuals in an employec-employer con. text use dimensions of dependence to evaluate and predict the tactics of the employee as well as the employer. The second experi. ment locuses on the countertactics of the employer (target of influence). Unlike the first experiment, the next one provides respondents information on the particular vactic adopted by the employee (as well as the four dimensions of dependence) and considers the effect of the employee's spercific actic on the individual's use of depend. ence to anticipate the employer's (target) response.

\section{Experiment Two}

The second experiment addresses two questions: First, will differemt employec tirctics lead inclividuals to use different dimensions of dependence to predict the employer's multilacic response? Second, given that the employec has already adopted a specific tactic, does a "tactic-matching" principle enter into inclividuals' prediction of the employer's response?

Regarding the firsl question, we offer the following corollary to the basic assump. (ions in the introduction: if the employee uses an indirect factic (self-enhancement or conlition), individuals will use the dependence dimension that the employee attacks to predict the employer's mullitactic re. sponse. The indirect tactics attark different itspects of employer's dependence; selfenhancement is direeted at the employer's value, while a coalition is directed at the employer's alternatives. Therefore, if the employee actopts self-enhancement, individuals will predict the employer's multilactic response from the employer's own value; on the other hand, if the employee 
sclects a coalition tactic, the employer's alternatives will be used to predict the employer's response. In sum, although the first experiment failed to observe any effects of dependence on indirect tactics, the second experiment determines whether the employee's use of these indirect tactics affects the employer's response. No hypotheses for the direct tactics are offered because these tactics do not attack the employer's dependence situation.

The second goal of this experiment is to determine whether and how individuals use a "tactic-matching" principle. Experimental research in a variety of contexts indicates that actors often match their opponent's taclics. Threats often lead to counierthreats, cooperation to cooperation, and concessions to concessions. 16 Matching on a behavioral level is well documented, at least in bilateral-power contexts, but the present research is concened with whether indlividuals cognitively" use the "matching principle" to aid the subjective prediction of Iactics.

The tactic-matching principle is a rather strict variant of the reciprocity notion. The reciprocity principle suggests that people benefit llose who benefit them and harn those who harm them. 'The matching principle, more specifically, suggests a tit-fortat form of reciprocily whereby parties engage in behavior that is as comparable as possible to the other party's behavior. 'The comparalsility of the behaviors may vary across different social contexts, and the potential for precise or exact matching requires that both parties have similar behavioral repertoires. The present study provides actors (employees and employers) with the same options and thereby permits the strictest possible application of the matching principle. In lhis context, support for the matching principle is suggested to the extent that inclividuals expect the em-

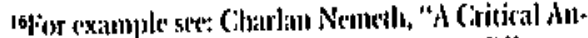
alysis of Reseateb (1)ilizing the Prisonet's Dilemuma paratigno for the Study of Barginining." in I.comare Berkowitu, edl., Adtances in Experimemal Sorin' Psyrhology (New York: Academic Press, I972), Vol. 6.

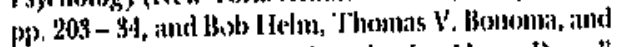
Jatues I: Tedeschi, "Recigresily Ier Hawn Dome," Joutruat of Social Psychology, Vol. 87, First I talt (June 1972), jus. 80 - 98.
}

ployer to adopt the same behavioral option as the employee (such as a threat to replace by the employer in response to a threat to quit by the employee).

An application of the power-lependence notion further suggests that the dimensions of dependence will modify expectations of tactic matching. Individuals should perceive a greater tendency toward tactic matching when power-dependence conditions are favorable to the particular tactic. Specifically, they slould expect the em. ployer to match (1) a llireat to quit with a threat to replace especially when the employer has good alternatives, (2) conllict avoidance with conflict avoidance when the employer attaches low value to the outcomes, $(3)$ a coalition with a coalition when the employee has good alternatives, and (4) self-enlancement with self-enhancement when the employee attaches low value to the outcomes. In sum, the second experiment will determine whether individuals expect a matching response and whether the dimensions of dependence modify these expectations.

\section{Method}

The design and procedures were identical to the first experiment. The same number of subjects (528) were randomly assigned to conditions, but none of these subjects had participated in the first experiment. The questionnaire items (tactics) were identical except that the subjects estimated the likelihood of the employer adopting the four options in response to each of the four employee tactics. That is, for each employee action, subjects estimated the likelihool of the employer responding with a threat to replace the employce, self-ctiliancement, coalition, and conflict avoidance (a total of 16 items, 4 in response to each employec (actic).

\section{Results: Multivariate ANOVAs}

Multivariate analyses of variance were run to determine which dependence dimensions are used to evaluate and predict the employer's multitactic response to each of the four employee tactics.

Employer's response to indirect lactics. The results support both hypotheses. A 
multivariate ANOVA on the employer's response to the employee's self-enhance. ment tactic revealed a main effect for employer's value $(\mathrm{F}=12.09, \mathrm{p}<.001$, canonical $\mathrm{R}=.30$ ) and no effects for the other dimen. sions of dependence. Data on the employer's response to a coalition revealed a main effect lor the employer's alternatives $(f=6.24$, $p<.001$, canonical $R=.22$ ) and no effects for the other dependence dimensions. Consistent with the hypotheses, the dimension of dependence attacked by the employec's tactic was used to anticipate the employer's response.

Employer's response to direct tactics. Although no explicit hypotheses were presented for direct tactics, the results indicate that individuals use different dimensions of dependence to predict the employer's respouse to conflict avoidance and to a threat to leave. Subjects used only the employer's value in predicting the response to the em. ployee's conflict avoidance $\left(F^{*}=6.11, p<, 001\right.$, canonical $R=.21$ ). In contrast, when the employer was confronted with a threat to leave by the employee, individuals used three dimensions of dependence to predict the employer's response: employer's alter. watives $(\mathrm{F}=25.27, \mathrm{p}<.001$, camonical $\mathrm{R}=$ .11), employer's value $(F=5.30, p<.001$, canonical $\mathrm{R}=.20$ ), and the employee's alternatives $(k=7.42, p<.001$, canonical $R=$ .23). Based on the canonical correlations, the employer's alternatives had the strongest effect. In sum, the employer's value is used to predict the employer's multilactic response to conflict avoidance, and the employer's alternatives are given the greatest weight when individuals predict the employer's reaction to a threat to leave.

Univariate effects. The links between specific dimensions of dependence and specific tactics replicate the effects of the first experiment.

\section{Results: Tactic-Matching}

The perceived likelihood of each em. ployer response to each employee betravior is shown in Table 4. The tactic-matching means are on the diagonal. For a given tactic, a consistent pattern toward matching is suggested if the matching mean (diagonal) is larger than any of the means down the column and across the row intersecting at the matching cell, Using a i-test for correlated means (see Appendix) to compare the matching cell with each of the correspond. ing column and row cells, we find that individuals expect the employer to match threat-to-leave and coalition responses, but not conflict-avoidance. The data for self-enlancement show only a weak tendency toward matching.

Although the perceived likelihood of matching varies for different responses, the tendency toward matching could be a function of the dimensions of dependence. To determine the effects of dependence, a matching score for each response was com.

Table 4. Mean Subjective Likelihood of Lach Limployer Response by the Type of Employee Tactic."

\begin{tabular}{|c|c|c|c|c|}
\hline $\begin{array}{l}\text { Eimployess" Tae } \\
\text { Enployer's } \\
\text { Response }\end{array}$ & $\begin{array}{l}\text { Threat io } \\
\text { Leave (T) }\end{array}$ & Conlition (c) & $\begin{array}{c}\text { Self } \\
\text { Buhnomsement (S) }\end{array}$ & $\begin{array}{c}\text { Conflict } \\
\text { Aroidanter (J) }\end{array}$ \\
\hline $\begin{array}{l}\text { Thwer to } \\
\text { leave (D) }\end{array}$ & 5.9] & 4,63 & 2.81 & $1.26 j$ \\
\hline Conlition (C) & 3.10 & 5,22 & 2.193 & 1.70 \\
\hline $\begin{array}{l}\text { Sell } \\
\text { entbinternerut (\$) }\end{array}$ & 5.50 & 5.05 & 5.56 & 3.57 \\
\hline $\begin{array}{l}\text { Comflict } \\
\text { itvoidinnce (A) }\end{array}$ & $3.9 \mathrm{~J}$ & 4.52 & 5.31 & 3.59 \\
\hline
\end{tabular}

"See Appernelix fer cortelated means. 
puted. ${ }^{17}$ As in the first experiment, hypolleses regarding direct tactics are confirmed and those concerned with indirect tactics are disconfirmed. Individuals perceive a greater tendency toward matching a threat. to-leave tactic when the employer has many rather than few alternatives, and they see the employee as more inclined to match conflict-avoidance when the employer attaches low rather than high value to the outcomes at issue. These data suggest that the overall matching trend for threats to leave is accentuated when the employer has many alternatives, while the negligible overall trend for matching conflict-avoidance in. creases slightly under the circumstances of low employer value.

\section{Discussion}

The results indicate that the type of tactic used by the employee has a bearing on the anticipated tactical response of the employer. With regard to indirect tactics, individuals use the dejendence dimension that the tactic attacks in order to anticipate the response of the employer. Specifically, individuals predict the employer's response to a self-enhancement tactic from the em. ployer's outcome value, the dimension of dependence that the self-cuhancement tactic attacks. T'hey predict the employer response to a coalition solely on the basis of the employer's outcome alternatives, the dimension of dependence that coalition altacks. Thus, while the data from experiment one suggest that the selection of indirect tactics is not affected by the dependence dinensions, data from experiment two lead us to qualify this conclusion. Dejendence cri-

\footnotetext{
IrThe four menth within wach coluun of lable 1 were ustrl to construct matehing scores for each tactic separately. The scores were constructed for ench tactic by suluracting the avelatge likelihoorl of nommatcling responses (witlin a colutum) from the me:an likelihood of maching tactics (within that sime column). lor extmple, if the employec atopls a threal-to-quil tactic, a theet to replate by the employer is the matcl.

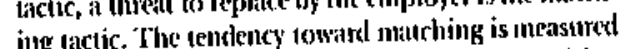
by sumbung the mean likelibood of the nombatching

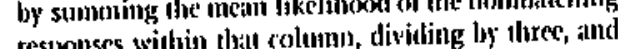
resjonses within thang thalue from the mean likclihock

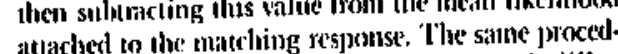
are is used for eaclu cunployer response, the only differ. conce being that the matching and nommatroing ve. sponses change with the employee tartic.
}

teria do affect the employer's selection of indirect tactics in response to the employee's use of indirect tactics.

The direct tactics also have a bearing on the dependence criteria that underlie countertactic predictions. Specifically, individuals use only the employer's outcome value to predict the employer's response to conflict avoidance; and the employer's alternatives, primarily, to predict the employer's response to a threat to leave. The overall implication is that individuals will identify the dependence dimension underlying the employee's direct tactic and use that same aspect of the employer's situation to predict the employer's response. For example, a threat to quit by an employee is grounded in the employee's own alicrnatives, and in. dividuals will use an analogous aspect of the employer's dependence situation (outcome alternatives) to predict the employer's response. The reciprocal dependence dimension forms the foundation for predicting the employer's response to direct tactics.

The "lactic-matching" hypotheses are supported for the direct tactics but not for the indirect tactics. The employer is viewed as more likely to matcli a threat to leave when the employer has many rather than few alternatives and as more likely to opt for conflict avoidance in response to conflict avoidance when the employer's value is low rather than high. In contrast, inclividuais expect matching responses to coalitions regardless of the dependence conditions. The weak overall tendency toward matching self-enlancement is also not modified by dependence conditions.

\section{Summary and Conclusions}

Subjectively predicting taclics appears to be an integral element of most conflict situations. As in everyclay life, parties in a conflict situation will adjust their actions not only to the situational or structural context but also to their expeclations of how their opponent will respond to this context. Indeed, this appears to be a critical determin. ant of success in conflict settings just as it is a key to maintaining harmonious relations in everyday life. A recent book on intelligence gathering in World War II, in fact, suggesss that the success of the Allies was 
not based simply on power or military force but also on their ability to predict the tac. tical moves of Germany and adjust their own moves accordingly. ${ }^{18}$ It is clear that multiple tactic judgments and predictions are important. The present research ad. dressed the issue of how people usc information on power dependence to formulate multitactic decisions and predictions.

To summarize, the research has four im. plications. First, the most general implication is that individuals use an actor's (whether employee or employer) own dependence, but not the opponent's dependence, to predict the actor's multitactic be. havior. Both experiments consistently affirm this notion. Second, different aspects of the actor's dependence are used to predict different actor tactics. Both experiments indicate that individuals use an actor's outcome alternatives to predict the likelihood of a threat to leave and the actor's ontcome vatue to predict the likelihood of conflict avoidance. Thircl, the second experiment suggests, furthermore, that individuals use different aspects of dependence to predict the actor's response to different lactics used by the opponemt. Specifically, they use an actor's alternatives to predict the actor's response to coalition and threat-10-leave tactics by the opponent, and they use an actor's value to predict the actor's response to self-enhancement and comflict avoidance. 'Ilye fourth implication of the research is that the dimensions of dependence affect differentially the perceived likelihood of lactic matching. Individuals view an actor as more likely to matels a threat to leave if he las good rather than poor outcome alternalives and conflict avoidance if Je altaches low value to the outcomes at issue.

'This paper reinforces our beliel lbat power-dependence theory provides an ap)propriate framework for the understinding of the cognitive processes underlying bargaining. Combining the lindings of this pajer with those in previous research shows that a dejendence approach to bargaining power allows us to understand three critical

\footnotetext{
Ief. W. Winterikutham, The Uttra Secret (New York: Dell I'ublishing (X). 1971).
}

cognitive issues in the bargaining process: (1) how bargainers estimate each other's power capabilities; ${ }^{19}$ (2) how bargainers assess the likelihood that each other will use his power, ${ }^{20}$ and (3) how bargainers evaluate and select among available tactics and anticipate the likely response to available tactics.

These issues and their resolution should not be the exclusive domain of abstract theorizing; they must also be confronted on a day-10-day basis and applied to very specific contexts by practitioners. Our methodology has admittedly been artificial and removed from the "real world." However, as George Strauss points oul, there are few experimentally derived hypotheses about bargaining that might not also be tested in ongoing labor-management relations." ${ }^{21}$ On the other hand, one of the primary problems of moving from laboratory experiments to field applications is the unit of analysis. This study, like most experimental analyses of bargaining, has focused on individual bargaining, and the relationships discove ered herein may differ when analyzed in the context of bargaining between collec. ives.

The prime importance of this paper is that it presents and empirically examines a new framework for linking the analysis of power and tactics in bargaining. The research affirms the validity of the framework in a preliminary way, and this is the primary role of experimentation in the bargaining field. Field observation may modily our basic framework, suggesting new experiments that may then suggest new ways to organize field observations. In this sense, the experiments in this paper represent not an end point but an important step in the dialectic between experimentation and field studies.

\footnotetext{
"Bacharach and lawter, "The perception of Power."

${ }^{20}$ Latwlet and Bitcharach, "Power Dependence in Indlividual liargaining."

"George Strauss, "Can Social Psychology Con. Iribute to Inelustrial Relations?" in Ceoffrey $M$. Stephanson and Christopher J. Brotherton, eds., Industrial Relations: A Social Psychological Approach (New York: Wiley, 1979), pp. 965-93.
} 
Appendix

T.Tests for Correlated Means

Shown in Table 4.

\begin{tabular}{|c|c|c|}
\hline Comparison & $\begin{array}{c}\text { Wean } \\
\text { Difference }\end{array}$ & $\begin{array}{c}\text { Matched } \\
1\end{array}$ \\
\hline \multicolumn{3}{|l|}{$\begin{array}{l}\text { Threat to leave } \\
\text { matching (l'T) }\end{array}$} \\
\hline 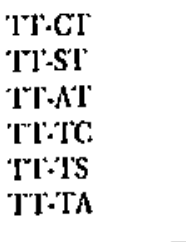 & $\begin{array}{r}1.27 \\
3.07 \\
4.65 \\
2.51 \\
.51 \\
2.00\end{array}$ & $\begin{array}{r}9.96^{*} \\
28.12^{*} \\
41.91^{*} \\
19.91^{*} \\
3.47^{*} \\
12.71^{*}\end{array}$ \\
\hline \multicolumn{3}{|l|}{$\begin{array}{l}\text { Coalition } \\
\text { matcling (C()) }\end{array}$} \\
\hline $\begin{array}{l}\text { CC.TC } \\
\text { CC-SC } \\
\text { CC.AC } \\
C C \cdot C{ }^{\prime} \\
\text { CC-CS } \\
\text { CC-CA }\end{array}$ & $\begin{array}{r}1.82 \\
2.29 \\
3.52 \\
.59 \\
.17 \\
.70\end{array}$ & $\begin{array}{c}18.13^{*} \\
21.23^{*} \\
28.62^{*} \\
4.39^{*} \\
1.23 \\
1.61^{*}\end{array}$ \\
\hline
\end{tabular}

Sell-enltaucement mitching (SS)

\begin{tabular}{lrc} 
SS.CS & .51 & $1.99^{*}$ \\
SS.TS & .20 & 2.00 \\
SS.AS & 1.48 & $11.13^{*}$ \\
SS-ST & 2.73 & $22.80^{*}$ \\
SS-SC & 2.64 & $22.33^{*}$ \\
SS.SA & .26 & 2.10 \\
\hline
\end{tabular}

Coullicl anvoiltance

matrbing $(A M)$

\begin{tabular}{lrc} 
AACA & -.93 & $7.33^{*}$ \\
A.IA & .32 & 2.89 \\
M.SA & -1.72 & $17.66^{*}$ \\
AA.AC & 1.88 & $17.69^{*}$ \\
AAAT & 2.34 & $25.10^{*}$ \\
$M A-A S$ & .02 & .11 \\
\hline
\end{tabular}

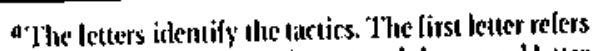
to the employec's tactic (columu) and the second letier identifies the enuployer's response (row). For example, 1\%I.CI refers to the upper left cell (employee uses hreat-10-leave bactic and employer respontls with in thent-10-leave tactic) mitus the CT cell (employee coalition and a threat-lo-leave response by the employer).

$*_{1}<.001$. 